University of Nebraska - Lincoln

DigitalCommons@University of Nebraska - Lincoln

\title{
Downstream Approaches to Phosphorus Management in Agricultural Landscapes: Regional Applicability and Use
}

\author{
R. Kröger \\ Mississippi State University, rkroger@cfr.msstate.edu \\ E. J. Dunne \\ St. Johns River Water Management District \\ J. Novak \\ USDA-ARS \\ K. W. King \\ USDA-ARS \\ E. McLellan \\ Environmental Defense Fund
}

See next page for additional authors

Follow this and additional works at: https://digitalcommons.unl.edu/usdaarsfacpub

Kröger, R.; Dunne, E. J.; Novak, J.; King, K. W.; McLellan, E.; Smith, D. R.; Strock, J.; Boomer, K.; Tomer, M.; and Noe, G. B., "Downstream Approaches to Phosphorus Management in Agricultural Landscapes:

Regional Applicability and Use" (2013). Publications from USDA-ARS / UNL Faculty. 1384.

https://digitalcommons.unl.edu/usdaarsfacpub/1384

This Article is brought to you for free and open access by the U.S. Department of Agriculture: Agricultural Research Service, Lincoln, Nebraska at DigitalCommons@University of Nebraska - Lincoln. It has been accepted for inclusion in Publications from USDA-ARS / UNL Faculty by an authorized administrator of DigitalCommons@University of Nebraska - Lincoln. 


\section{Authors}

R. Kröger, E. J. Dunne, J. Novak, K. W. King, E. McLellan, D. R. Smith, J. Strock, K. Boomer, M. Tomer, and G. B. Noe 
Review

\title{
Downstream approaches to phosphorus management in agricultural landscapes: Regional applicability and use
}

\author{
R. Kröger a,*, E.J. Dunne ${ }^{\text {b }}$, J. Novak ${ }^{c}$, K.W. King ${ }^{\text {d }}$, E. McLellan ${ }^{\text {e }}$, D.R. Smith ${ }^{\mathrm{f}}$, J. Strock ${ }^{\mathrm{g}}$, K. Boomer ${ }^{\text {h }}$, \\ M. Tomer ${ }^{\mathrm{i}}$, G.B. Noe ${ }^{\mathrm{j}}$ \\ a Department of Wildlife, Fisheries and Aquaculture, Mississippi State University, Mississippi State, MS, USA \\ ${ }^{\mathrm{b}}$ Bureau of Environmental Sciences, St. Johns River Water Management District, Division of Water Resources, 4049 Reid Street, Palatka, FL 32177, USA \\ c USDA-ARS, Coastal Plains Research Center, 2611 W. Lucas Street, Florence, SC 29501, USA \\ d United States Department of Agriculture-Agricultural Research Service, Soil Drainage Research Unit, 590 Woody Hayes Drive, Columbus, OH 43210 , USA \\ e Environmental Defense Fund, 1875 Connecticut Avenue, N.W., Washington, DC 20009, USA \\ ${ }^{\mathrm{f}}$ USDA-ARS, National Soil Erosion Research Laboratory, 275 S. Russell Street, Purdue University, West Lafayette, IN 47906, USA \\ g University of Minnesota, 23669 130th Street, Lamberton, MN 56152, USA \\ h The Nature Conservancy of Maryland/DC Office, 5410 Grosvenor Lane, Suite 100, Bethesda, MD 20814, USA \\ i USDA-ARS, 2110 University Blvd. Ames, IA 50011, USA \\ j USGS, 430 National Center, Reston, VA 20192, USA
}

\section{H I G H L I G H T S}

- Understanding effective P management requires understanding the relevant portions of hydrological and biogeochemical cycles.

- Across landscapes, a downstream ecologically engineered approach to P management requires regional tailoring.

- Downstream approaches are structured linearly EOF, to adjacent aquatic systems and to broader landscape systems.

- All management approaches have challenges and opportunities that need to be overcome to ensure P management.

\section{A R T I C L E I N F O}

\section{Article history:}

Received 13 June 2012

Received in revised form 8 October 2012

Accepted 8 October 2012

Available online 22 November 2012

\section{Keywords:}

Phosphorus

Best management practice

Aquatic system

Agriculture

\begin{abstract}
A B S T R A C T
This review provides a critical overview of conservation practices that are aimed at improving water quality by retaining phosphorus $(\mathrm{P})$ downstream of runoff genesis. The review is structured around specific downstream practices that are prevalent in various parts of the United States. Specific practices that we discuss include the use of controlled drainage, chemical treatment of waters and soils, receiving ditch management, and wetlands. The review also focuses on the specific hydrology and biogeochemistry associated with each of those practices. The practices are structured sequentially along flowpaths as you move through the landscape, from the edge-of-field, to adjacent aquatic systems, and ultimately to downstream P retention. Often practices are region specific based on geology, cropping practices, and specific P related problems and thus require a right practice, and right place mentality to management. Each practice has fundamental P transport and retention processes by systems that can be optimized by management with the goal of reducing downstream P loading after P has left agricultural fields. The management of $\mathrm{P}$ requires a system-wide assessment of the stability of $\mathrm{P}$ in different biogeochemical forms (particulate vs. dissolved, organic vs. inorganic), in different storage pools (soil, sediment, streams etc.), and under varying biogeochemical and hydrological conditions that act to convert P from one form to another and promote its retention in or transport out of different landscape components. There is significant potential of hierarchically placing practices in the agricultural landscape and enhancing the associated P mitigation. But an understanding is needed of short- and long-term P retention mechanisms within a certain practice and incorporating maintenance schedules if necessary to improve P retention times and minimize exceeding retention capacity.
\end{abstract}

\section{Contents}

1. Introduction ..... . . 264

2. The $\mathrm{P}$ cycle in agricultural landscapes-managing complexity . . . . . . . . . . . . . . . . . . . . . . . . . . . . . . . . . . . . . .

\footnotetext{
* Corresponding author at: Box 9690, Mississippi State, MS 39762, USA. Tel.: +1 6623254731

E-mail address: rkroger@cfr.msstate.edu (R. Kröger).
} 


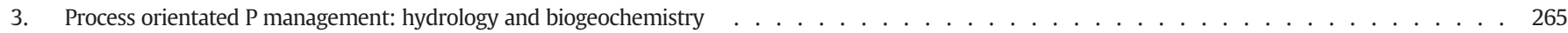

3.1. Hydrological manipulations for effective P management . . . . . . . . . . . . . . . . . . . . . . . . . 265

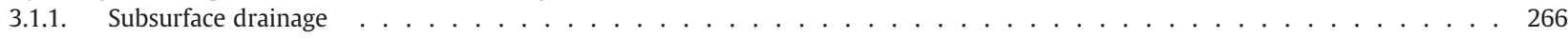

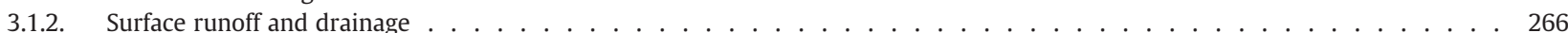

3.2. Biogeochemical processes affecting P transport and bioavailability . . . . . . . . . . . . . . . . . . . . . . . . 266

3.2.1. Soil P management . . . . . . . . . . . . . . . . . . . . . . . . . . . . . 267

4. Right practice, right place! . . . . . . . . . . . . . . . . . . . . . . . . . . . . . . . . . 267

4.1. Edge-of-field practices and designs for P management . . . . . . . . . . . . . . . . . . . . . . . . . . 267

4.2. Filtering $\mathrm{P}$ on the edge: biogeochemical treatment of surface and subsurface runoff . . . . . . . . . . . . . . . . . 268

4.3. Hydrology management - water table management at the end-of-tile . . . . . . . . . . . . . . . . . . . . . . . . 269

4.4. Hydrological manipulations and design of surface drainage to enhance particulate P retention . . . . . . . . . . . . . . . . . . . . 269

4.5. Wetlands and treatment systems of landscape practices as tools for downstream P management . . . . . . . . . . . . . . . 270

5. Policy challenges of P management from the watershed scale . . . . . . . . . . . . . . . . . . . . . . . . . . . . . . 271

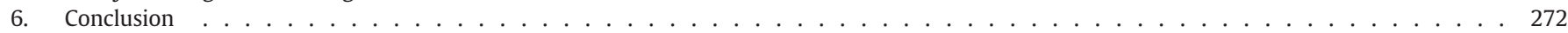

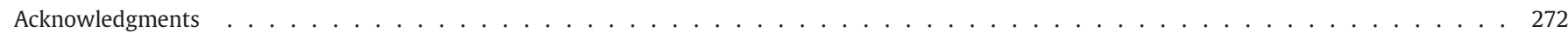

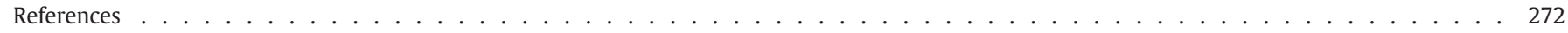

\section{Introduction}

While phosphorus (P) plays an important role as a plant nutrient in a variety of landscapes, its loss to downstream aquatic systems creates local and regional water quality problems in the United States and around the world (Dale et al., 2010; Diaz and Rosenberg, 2008). In freshwater systems, P is commonly a limiting nutrient (Elser et al., 2007). It can stimulate eutrophication, creating large algal blooms and result in oxygen depletion. Eutrophication degrades water quality, negatively impacts ecosystems, and has significant economic impacts in both the rural and urban landscape. Phosphorus-related water quality problems in the Great Lakes, Florida Everglades and elsewhere cause over $\$ 2.2$ billion/year in economic impacts (Dodds et al., 2009). Further downstream, in estuaries such as the Chesapeake Bay, Florida Keys, and the Gulf of Mexico recent studies suggest that P also plays a secondary, yet important role in the occurrence of hypoxia (Rabalais, 2002; Rabalais et al., 2002; Robertson et al., 2009; Sylvan et al., 2006; USEPA, 2007) (Fig. 1). In the Gulf of Mexico 45\% reduction in nitrogen (N) and $\mathrm{P}$ loads will be needed to reduce the size of the "dead zone" to acceptable levels (Dale et al., 2010). While a variety of sources contribute to downstream P loading, agriculture often plays a dominant role (Burkart and James, 1999; McDowell et al., 2008; Preston et al., 2011; Rabalais et al., 1996; Sharpley et al., 2003). There is increasing societal awareness of and concern for the degradation of natural resources, and specifically downstream water quality impairments as a result of agricultural production. In the United States this concern is reflected in the current policy discussions at both Federal and State levels. Government entities desire increased accountability to agriculture's impact

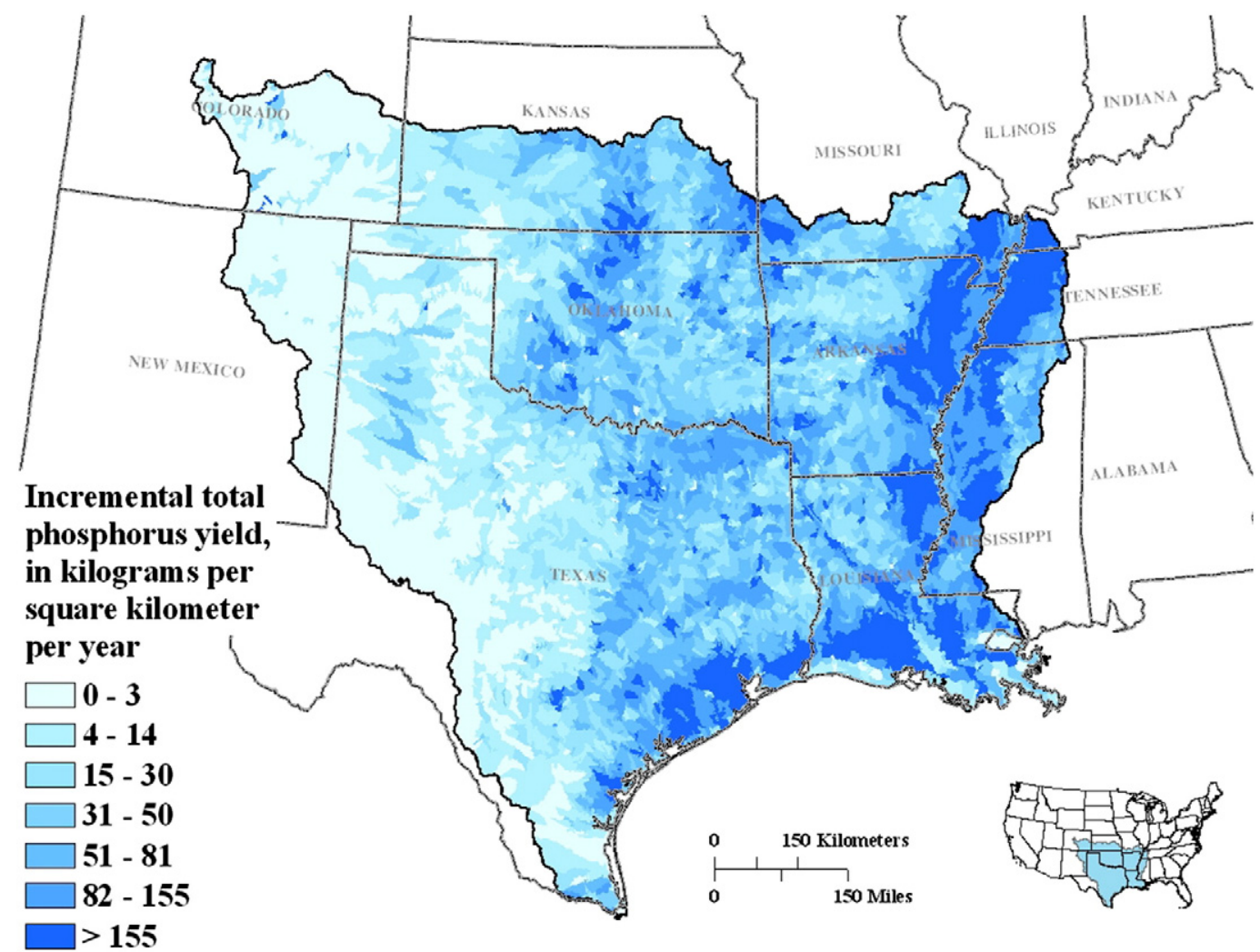

Fig. 1. Incremental yields of total phosphorus in kilograms per square kilometer per year to the North-western Gulf of Mexico from streams in the South-central United States. Modified from Rebich et al. (2011). 
on the environment, but are reluctant to impose regulatory requirements, which are in any case difficult to design and enforce to control and mitigate nonpoint source loss of nutrients. This makes adoption of more responsible, voluntary management practices a preferred option of producers (Strock et al., 2010). In addition, new schemes that implement market-like programs that financially support farmers for producing environmental services like good water quality are gaining popularity (Bohlen et al., 2009).

The effectiveness of the different practices used to reduce P delivery from agricultural landscapes to downstream aquatic systems varies based on P species, topography, soils, vegetation, climate, land management regime, hydrology and technology applicability. Solutions can vary from low- to highly engineered solutions, including the use of natural and engineered materials for $\mathrm{P}$ adsorption and precipitation (Boyer et al., 2011). Ecological approaches also have been developed to mitigate excess P delivery from agriculture to downstream aquatic systems. An ecological engineering approach relies on self-design of ecosystems (minimal human intervention and management after initial construction), is based on sound physical science, and relies on a holistic approach to conserving resources and ecosystems (Mitsch and Jørgensen, 2004). An ecologically engineered approach integrates with and compliments a watershed approach that incorporates social partnerships, a geographic focus, and management techniques that are grounded in sound science. Using ecologically engineered systems lends itself to a multidisciplinary approach to solving nutrient problems at field- and watershed-scales. For example, an ecologically based approach would include the use of buffers, wetlands, controlled drainage, and instream techniques to create a treatment chain of management practices across the landscape to reduce P loss from agriculture (Braskerud, 2002; Dunne et al., 2007; Kadlec et al., 2010; Reddy et al., 1998; Strock et al., 2010). All of these approaches can be termed downstream reduction approaches as they are downstream of runoff sources. However, regional variables of climate, topography, hydrology and soil, along with agricultural practices, which can include drainage, cropping type, and nutrient management, limit the applicability of a single practice Thus, because $P$ problems and ecological engineering solutions vary by region, there is a need for tailored ecological approaches for regions that are specific to topographic, hydrologic, and biogeochemical settings to maximize P mitigation downstream.

The long-term goal of mitigating $\mathrm{P}$ loss to downstream aquatic systems depends upon converting it to more stable forms (i.e., refractory forms of $\mathrm{P}$ such as sorption of $\mathrm{PO}_{4}$ to $\mathrm{Al}$ hydroxides) and storing it in ecosystem compartments that offer longer-term storage. Our paper focuses on the role that specific ecologically based practices can play and are already playing - in regions as diverse as the coastal plains of Carolina, lacustrine areas of the Great Lakes, alluvial delta regions of Mississippi and Arkansas, and glacial till of the upper Midwestern US. The objectives of our synthesis are to:

- outline and illustrate the relevant portions of the hydrological and biogeochemical processes that are responsible for $\mathrm{P}$ transport to and storage in downstream systems

- demonstrate several key approaches to P management strategies that are used in agricultural landscapes within the US

- consider a common ecologically engineered approach to achieve a solution to downstream P management in agricultural landscapes

- outline challenges and opportunities facing scientists, managers and policy makers to ensure effective P management

This review provides a critical overview of conservation practices aimed at improving water quality by retaining $P$ in various landscape settings. It is not only structured around specific practices that are prevalent in various parts of the US, but also focuses on the specific hydrological and $\mathrm{P}$ biogeochemical processes associated with each practice that makes them effective for P retention. The practices are structured sequentially along flowpaths as you move through the landscape, from the edge-of-field, to adjacent aquatic systems conducive to management strategies, and ultimately to broader landscape systems that aim to address problems of legacy nutrients and downstream $P$ retention.

\section{The $P$ cycle in agricultural landscapes-managing complexity}

Agricultural landscapes, especially in the above mentioned regions, are intensively managed to successfully produce food, fiber and biofuel crops to meet the expected demand of an increasing world population (Petrolia and Gowda, 2010; Wilhelm et al., 2010). Additionally, the shift from raising range animals to production in confined animal operations across the US has intensified manure production resulting in soils that have met or exceeded their capacities to store nutrients in some watersheds (Kellogg et al., 2000). This intensification of land use activity has caused both direct and indirect impacts to the receiving environment, which include nutrient runoff, greenhouse gas emissions from soils, and land degradation through increased erosion. These characteristics inevitability will degrade both soil and aquatic ecosystems potentially resulting in lower crop yields and poor water quality. Often, there is little opportunity to off-set these characteristics by ecologically restoring portions of severely impacted landscapes/ecosystems. However, there are sections of agricultural landscapes that can be managed and enhanced to provide soil and water quality improvements (Delgado et al., 2011), in addition to other ecosystem services.

Solutions to $\mathrm{P}$ control and reducing loss are decreasing initial $\mathrm{P}$ inputs, slowing $\mathrm{P}$ transport off of agricultural land use, and increasing retention of $\mathrm{P}$ in the landscape in either dissolved or particulate P forms. Agricultural practices can be modified to decrease P inputs to fields. There is a plethora of literature on field-level practices and how they have decreased P loading when successfully implemented (Kleinman et al., 2011; Maguire et al., 2009; Sharpley and Halvorson, 1994; Sharpley et al., 1994, 2009). Our review focuses on fundamental P transport and retention processes across the agricultural landscape and reducing downstream $\mathrm{P}$ loading by using appropriate practices at various scales.

Long-term sorption, storage, and burial of $\mathrm{P}$ in soil and newly accreted soil and sediment are the mechanisms to remove $P$ from active ecosystem cycling. Many pathways in the P cycle, however, include rapid transformation of $\mathrm{P}$ from one species to another in response to changes in environmental (e.g. redox, pH) conditions. Some of these transformations release $\mathrm{P}$ back into the environment in biologically available forms. For this reason, management of $\mathrm{P}$ is complex and it requires an understanding of the dominating processes within a given landscape setting. Several management techniques could retain certain $P$ forms (i.e. accumulation of sediment and particulate $\mathrm{P}$ ), while simultaneously creating conditions for the release of other $P$ forms (e.g., reduction of iron and desorption of phosphate anion). The management of $P$ requires a system-wide assessment of the stability of $\mathrm{P}$ in different biogeochemical forms (particulate vs. dissolved, organic vs. inorganic), in different storage pools (soil, sediment, streams etc.), and under varying biogeochemical and hydrological conditions that act to convert P from one form to another and promote its retention in or transport out of different landscape components. When describing and illustrating management strategies for $P$, it is essential to discuss the pertinent physical and chemical mechanisms that control $\mathrm{P}$ transformation and transport in a given landscape setting. We advocate that to effectively reduce $\mathrm{P}$ loss to downstream systems the hydrology and biogeochemistry of both the practice and the place (landscape setting) must be understood.

\section{Process orientated P management: hydrology and biogeochemistry}

\subsection{Hydrological manipulations for effective P management}

Relevant hydrologic processes include the transportation of $\mathrm{P}$ within and from the agricultural landscape via subsurface and surface 
pathways, as well as alterations in flows which change hydraulic residence time (HRT) and water velocity. Altering HRT changes contact time for biological and chemical processing, as well as changes water velocity that influence shear stress and sediment entrainment and deposition. Transport pathways determine $\mathrm{P}$ runoff type and are typically specific to various regions of the US based on soil characteristics and drainage management (i.e., surface drainage in areas with low soil profile hydraulic conductivity). Phosphorus, whether in a particulate or dissolved phase can be transported from the agricultural landscape via subsurface tile drainage, or surface drainage ditches (Gentry et al., 2007; Kleinman et al., 2007a, 2007b; Kleinman et al., 2011; Macrae et al., 2007).

\subsubsection{Subsurface drainage}

Subsurface drainage as a dominant source of $\mathrm{P}$ is prevalent in the Midwestern United States wherein an excess of 20.6 million ha ( $37 \%$ of the tillable land) is managed with subsurface drainage (Zucker and Brown, 1998). The flat glacial plains of the Midwest were originally wetlands and marshes, and were drained to convert these areas into some of the world's most productive croplands. However, subsurface tile drainage also provides a rapid conduit for transport of agricultural nutrients to downstream waters. Depending on soils and site specific characteristics, the amount of dissolved $P$ routed through subsurface drainage may be significant (Heathwaite and Dils, 2000). Phosphorus concentrations measured at the end of tiles often exceed current and proposed designated use recommendations for downstream aquatic ecosystems (Sims et al., 1998). Tomer et al. (2008) in Iowa's south fork watershed found that most (approximately $75 \%$ ) of tile drainage samples had dissolved P: total P ratios $>0.9$. Dissolved $\mathrm{P}$ and total $\mathrm{P}$ concentrations in tile drainage generally increase with increasing discharge (Gentry et al., 2007), are highly variable, and typically show seasonal trends (Macrae et al., 2007). In a seven year study across four crop production fields, Algoazany et al. (2007) in east-central Illinois, found that soluble P concentrations recovered in the subsurface drainage was approximately $50 \%$ greater than that measured in surface runoff. Up to $40 \%$ of annual $P$ load measured at the edge of field could be contributed from tile discharge (Enright and Madramootoo, 2004). In a nested-scale hydrograph separation study, Tomer et al. (2008) estimated the total P load from tiles comprised $42 \%$ that observed at the watershed outlet during an individual rainfall runoff event in 2006, with stream banks contributing most of the remainder. The total P delivered in tile discharge, in turn was $>75 \%$ comprised of surface runoff which mostly entered the tile system through surface intakes (Tomer et al., 2008).

When managing subsurface drainage there is a need for designing conservation practices to address P delivery either within the subsurface drain (Sims et al., 1998) or prior to the runoff entering the tile drain system (Smith and Livingston, submitted for publication). Practices used to mitigate water and nutrient loss via tile drains can include water table management at the tile outlet (Martin et al., 1997; Ritzema et al., 2006; Strock et al., 2010; Thomas et al., 1991). Controlled drainage or controlled sub-irrigation slows runoff velocities, decreases outflow volumes, and increases the HRT of water in the soil profile (see later sections for further discussion). Another option to decrease particulate and dissolved P loading to the streams is to filter the runoff water before it enters the sub-surface tile lines using blind intakes and buffered intakes.

\subsubsection{Surface runoff and drainage}

Surface runoff and P delivery are explicitly linked to discharge volume (Sharpley et al., 2008). Edge-of-field and watershed scale studies have concluded that $\mathrm{P}$ (Gentry et al., 2007) loads are generally positively correlated with surface runoff volume and that transport with larger events is disproportional to that of smaller events (Kronvang et al., 2003; Pionke et al., 1996; Sharpley et al., 2008). In a 10 y study on a 39.5 ha subwatershed of Mahantango Creek in Pennsylvania, storm event surface runoff generated $32 \%$ of the watershed discharge but accounted for disproportionate amount of P loads (65\% of the dissolved P and 76\% of the total P load) (Sharpley et al., 2008). Similarly, Pionke et al. (1996) using a $9.7 \mathrm{~km}^{2}$ (970 ha) watershed in Pennsylvania found that the majority of $\mathrm{P}(70 \%)$ transport was generated by the largest three to five runoff producing events.

The major constraint in effective dissolved and particulate P management in surface runoff is discharge volume. Managing P delivery through surface runoff requires reducing the velocity of runoff as well as creating environmental conditions that promotes suitable HRT (whether at farm, field, or watershed scales), optimizes conditions for sedimentation, encourages aquatic life conducive for P adsorption and assimilation and sediment capture (e.g., aquatic plants with luxury uptake potential, increased surface area for microbial attachment), and increases the surface area of sediment to water volume of the water column ratio.

Maynard et al. (2009) highlighted the effectiveness of an inundated flow-through constructed wetland in the San Joaquin Valley, California on bioavailable P attenuation from agricultural irrigation tailwaters. Management of these systems typically involves increasing HRT, thus increasing the contact time for biological and biogeochemical nutrient assimilation and transformation. Increasing the sediment to water volume ratio maximizes contact for $\mathrm{P}$ ad- and absorption to the sediment, increases roughness which encourages sedimentation, and allows for newly deposited sediment to be buried (Kadlec, 1999; Leader et al., 2008; Reddy and Delaune, 2008). Furthermore these systems are created and managed to maximize the retention of specific $P$ forms.

If particulate $P$ is of interest, sedimentation will be the primary biogeochemical process governing $\mathrm{P}$ removal. If dissolved $\mathrm{P}$ is of interest, then adsorption and assimilation through biological processes would be optimized to retain P. However, there may be circumstances in the landscape where soils and sediments are laden with inorganic $P$ due to historical loading by past agricultural practices. Where legacy $\mathrm{P}$ problems exist, it may be appropriate to minimize HRT to avoid desorption and the development of geochemical reducing conditions that release dissolved phase P from soil into the overlying water column, while optimizing conditions for removing particulate $\mathrm{P}$ via sedimentation.

\subsection{Biogeochemical processes affecting $P$ transport and bioavailability}

Soil P biogeochemistry depends on soil or sediment type, their ability to sorb and desorb inorganic $P$, and how these sorption capacities change in response to environmental conditions largely controlled by water content and water chemistry. Primary environmental controls include $\mathrm{pH}$, redox, metal, and organic content.

Under natural conditions, P sorption in upland, oxygenated soils depends largely on soil mineralogy (King et al., 2010; Penn et al., 2010). For example, ferrous iron oxidation can immobilize $\mathrm{P}$ by inducing vivianite $\left(\mathrm{Fe}_{3}\left(\mathrm{PO}_{4}\right)^{2-}\left(\mathrm{H}_{2} \mathrm{O}\right)_{8}\right)$ precipitation particularly in P-enriched soils (Gächter and Müller, 2003; House and Denison, 2002). In acid upland soils ( $\mathrm{pH}$ less than 6), iron, aluminum, and manganese dissolve into soil solution, and rapidly combine with available phosphate to form insoluble hydroxyl phosphates (e.g., strengite $\left(\mathrm{FePO}_{4} \cdot 2 \mathrm{H}_{2} \mathrm{O}\right)$ and variscite $\left.\left(\mathrm{AlPO}_{4} \cdot 2 \mathrm{H}_{2} \mathrm{O}\right)\right)$. Similar processes can occur in circumneutral soils $(\mathrm{pH}$ greater than 6 and less than 8 ), though the reduced acidity leads to the formation of goethite $(\mathrm{FeOOH})$ or ferrihydrite $\left(\left(\mathrm{Fe}^{3+}\right)_{2} \mathrm{O}_{3} \cdot 0.5 \mathrm{H}_{2} \mathrm{O}\right)$ in temperate climates or hematite $\left(\mathrm{Fe}_{2} \mathrm{O}_{3}\right)$ and gibbsite $\left(\mathrm{Al}(\mathrm{OH})_{3}\right)$ in warm, tropical climates. In alkaline upland soils ( $\mathrm{pH}$ greater than 8 ), available phosphate combines with calcium ions to form less soluble compounds (e.g., tricalcium phosphate, $\left.\mathrm{Ca}_{3}\left(\mathrm{PO}_{4}\right)_{2}\right)$. The efficiency of $\mathrm{P}$ binding processes increases in fine-textured soils because of increased soil surface area and higher soil water holding capacities (Olson, 1977). In general, P readily sorbs to terrestrial soil particles, and erosion of soil particles provides the primary transport mechanism. 
In wet soils, the duration of flooding, the chemistry of the floodwaters, temperature, and water movement control P release and uptake through hydrologic control of internal geochemical reactions and microbial processes (Reddy et al., 1999). Anoxia affects soil chemistry differentially, depending on the supply of terminal electron acceptors. Under oxic conditions maintained by oxygenated or nitrate-enriched ground water, contrasting mechanisms can influence P-mobilization. Enhanced decomposition can mobilize organic-P (Olde Venterink et al., 2001). Alternatively, oxic conditions can reduce P availability by limiting ferric iron and $\mathrm{SO}_{4}^{2-}$ reduction (Patrick and Khalid, 1974). Sub-oxic conditions sustained by the presence of soil iron oxides and $\mathrm{SO}_{4}^{2-}$ influxes maximally influence $\mathrm{P}$ availability (Caraco et al., 1989). The redox-sensitive, Fe-bound P-pools are highly dynamic and affected by short-term processes (House, 2003; Richardson, 1995; Walbridge and Struthers, 1993); therefore, these pools predominantly control P-availability in wetlands (Sharpley, 1995). Aluminum bound $\mathrm{P}$ is also a significant component of $\mathrm{P}$ fraction pools in sediments. However, unlike Fe-P, Al-P is not affected by redox, but rather $\mathrm{pH}$ (Lijklema, 1980). Ultimately, P availability in any soil that is inundated or otherwise is the net difference between shortand long-term $\mathrm{P}$ retaining and releasing mechanisms.

\subsubsection{Soil P management}

Based on our current understanding of soil P dynamics, the following strategies can enhance $P$ retention in downstream agricultural landscape: 1) use soil amendments (e.g., organic-rich substrates such as biochar or calcium-rich substrates such as gypsum) to increase P sorption capacity; 2) oxygenate sediments to prevent phosphate desorption during $\mathrm{Fe}$ and $\mathrm{SO}_{4}$ reduction and subsequent phosphate release, 3 ) buffer $\mathrm{pH}$, thereby preventing acidic conditions that dissolve aluminum compounds and release $\mathrm{P}, 4$ ) promoting $\mathrm{OM}$ production, increasing phosphate adsorption, 5) preventing desiccation of sediments and soil to prevent microbial lysis and $\mathrm{P}$ release, and 6) increasing plant production and biomass $P$ incorporation to reduce phosphate loads at times when aquatic P demand is highest in downstream waterbodies.

Biogeochemical management of inorganic $P$ often centers on the addition of a geochemical substrate for P adsorption (e.g., gypsum curtains, biochar, alum, steel slags), and controlling environmental conditions that alter mineral solubility and P-adsorption mechanisms. Many of the approaches rely on chemical reactions to bind or sorb $\mathrm{P}$ and require contact with the media being used to 'filter' the P, and their limited longevity necessitates continual removal and addition of fresh substrate.

During water level drawdown in wetland environments, sediments are often exposed and oxidized, and organic matter decomposition and mineralization are enhanced (Newman and Pietro, 2001). The oxidation of organic soils and the senescence of aquatic macrophytes and microbial communities result in mineralization, cell lysis and release of P (Klotz and Linn, 2001). When re-flooded a number of biogeochemical processes occur in both aerobic and anaerobic conditions that result in dynamic P cycling (Baldwin, 1996). Phosphorus release due to hydrolysis of organic matter may occur under both aerobic and anaerobic conditions (Newman and Pietro, 2001). However, ephemerality of wetland systems adjacent to agricultural areas provides a juxtaposed drawdown/flooding continuum with heterogeneous anoxic/oxic areas available for variable $\mathrm{P}$ biogeochemical transformations.

Prolonged periods of saturated soil conditions increase available $\mathrm{P}$ by enhancing mineral solubility through several mechanisms, ultimately controlled by $\mathrm{pH}$ and redox conditions. Over the long term (annual to decadal or longer), increased soil moisture slows decomposition, and the higher organic matter content interferes with crystalline formation of the mineral precipitates (Walbridge and Struthers, 1993). The non-crystalline (amorphous) phosphate minerals which form instead more strongly sorb phosphate are more reactive (i.e., labile) and influenced by plant roots and microbial processes (Axt and Walbridge,
1999). Over short time spans (days to months), oxygen is rapidly depleted from the water-logged, saturated soils leading to reduced or sub-oxic conditions that enhance crystalline and amorphous iron mineral dissolution and $\mathrm{P}$ release rates (Boomer and Bedford, 2008; Roden and Edmonds, 1997). Sulfate reduction also can increase P release and availability by enhancing iron reduction and inducing iron sulfides (FeS) and pyrite $\left(\mathrm{FeS}_{2}\right)$ formation (Wetzel, 2001). These processes can be reversed when the watertable undergoes drawdown (Gambrell and Patrick, 1988; Newman and Pietro, 2001) or with the delivery of oxygenated or nitrate-enriched groundwater, which promotes iron-sulfate mineral precipitation and $\mathrm{P}$ co-precipitation (Lucassen et al., 2005; Roelofs, 1991).

\section{Right practice, right place!}

Spatial and temporal heterogeneity of agricultural practices, biogeochemical conditions, and hydrological manipulations of agricultural landscapes across the conterminous US result in variable management approaches to P retention. However, the basic two tenets of hydrology (volume and velocity) and biogeochemical management will be the central objectives of most management approaches. Phosphorus management will vary from creating suitable conditions for sedimentation, to enhanced chemical precipitation, to increased surface area and contact time for biological assimilation and the long-term storage of P via organic matter accrual and accretion. Most stakeholders (e.g., scientists, managers, regulatory agencies), regardless of the landscape situation, when faced with $\mathrm{P}$ management will encounter three distinct problems: 1) substituting one P problem for another, for example, increasing dissolved $\mathrm{P}$ runoff from agricultural soils saturated with $\mathrm{P}$, while retaining particulate $\mathrm{P} ; 2$ ) the persistence of $\mathrm{P}$ in field or within the management practice; and 3) the likelihood of persistent problems associated with P loss even if source control practices are successful.

Retention of $\mathrm{P}$, in either a particulate or dissolved form, by a given management practice is a function of four dominant processes: $\mathrm{P}$ loading rate, residence time (and velocity for suspended sediment), area of retention, and system geochemistry (Kadlec and Wallace, 2008). Depending on hydrologic and soil characteristics of a specific watershed (whether by region, or by hydrologic unit code), practices may be created and managed to enhance dissolved $\mathrm{P}$ adsorption, particulate $\mathrm{P}$ sequestration, or are managed for both dissolved and particulate $\mathrm{P}$ retention. However, maximizing the retention of dissolved and particulate $P$ requires optimizing different aspects of the hydro-biogeochemical cycle. For example, a BMP strategy to reduce dissolved P loads would emphasize P sorption capacity by soil and sediment, as well as vegetative biomass storage and subsequent organic matter accretion, while a practice strategy to reduce particulate $P$ from inflowing waters would emphasize sedimentation, by reducing incoming water velocities. Within the US there are several high intensity agricultural systems that have unique sets of hydrological and biogeochemical opportunities and challenges for P management. A downstream approach to P management is a suite of management practices that are placed in the landscape to manage $P$ (i.e., transformation or retention) that occur from the point of runoff (post source control) leaving the agricultural landscape. This downstream approach is in no way advocating the absence of input management or source control, rather both management approaches would operate in tandem to enhance P management and downstream water quality.

\subsection{Edge-of-field practices and designs for P management}

Utilizing a downstream approach to P management requires runoff interception at the edge-of-field as a first step. Edge-of-field practices are useful in P management through modifying surface runoff. In most intense agricultural areas such as the Upper Mississippi River Basin (UMRB), Great Lakes Watersheds (GLW), and Lower Mississippi Alluvial Valley (LMAV) the landscape is dominated by drainage ditches. Many of 
these ditches have been straightened, deepened, or widened to more rapidly convey agricultural surface and subsurface tile drainage waters (King et al., 2009). In addition many fields may require supplemental drainage to ensure that crops are not submerged for extended periods in low spots, known as pot-holes, bays, or depressional areas (Smith et al., 2008).

The relative proportion of cropped pothole wetlands in a watershed is correlated with P loss (concentration and load) in that watershed (Smith et al., 2008). One option to decrease sediment and P loads to the streams is to filter the runoff water in potholes before it enters sub-surface tile lines. This has been successfully accomplished using a practice known as a blind inlet or French drain (Fig. 2). French drains have been used in Minnesota to filter out sediments. This appears to have successfully decreased contaminant loading; however, siltation in the gravel greatly reduced the porosity of the gravel layer, thereby decreasing the ability of this design to maintain drainage while filtering contaminants. In Indiana, a design has been developed to avoid those issues (Smith and Livingston, submitted for publication). The French drain design in Minnesota uses a tile buried in gravel to the surface, which can fill with sediment thereby reducing the hydraulic efficiency. The blind inlet design being used in Indiana uses a tile buried in gravel, which is encased with a geotextile fabric to prevent silting in, and also has a course-textured layer of soil at the surface. The blind inlet design allows the farmer to perform field operations directly over the blind inlet, without reducing the hydraulic or nutrient retention efficiency. This design has successfully reduced TP loading by as much as $78 \%$ and soluble P loading by as much as $72 \%$, thereby reducing P loading on a watershed scale (DR Smith, 2012, unpublished data). Blind inlets are a new technology, but have been demonstrated to be effective at draining pot-holes for eight years, with an expected "lifespan" of about 15 years. Upland erosion will eventually decrease the hydraulic conductivity of the soil directly over the blind inlet. In such instances, practices that will improve the hydraulic conductivity over the blind inlet may need to be used periodically, including tillage to break up a crust should one develop, use of cover crops to encourage healthy soils to develop, and potentially the use of gypsum to encourage the formation of good soil structure.

In the LMAV, efforts are underway to create innovative edge-of-field management practices that reduce particulate $P$ delivery to downstream systems and immediately curtail the nutrient spiral potential of $\mathrm{P}$ with removal and replacement back on the agricultural landscape. A slotted pipe is a management practice that is being used on surface drained fields to minimize erosion on the primary drainage ditch by directing water through a conveyance device with a fixed elevation that prevents head cutting (Fig. 2). Slotted pipes as edge-of-field practices theoretically slow runoff velocities, detain a variable pool of water, and encourage sedimentation on the agricultural landscape. Kröger et al. (in review) documented how slotted pipes in the LMAV have distinct active sediment accumulation phases (approximately 235 days following installation $\sim 1.5 \mathrm{~mm} /$ day) and passive accumulation/scouring phases (235-634 days - $0.03 \mathrm{~mm} /$ day). Data has highlighted that slotted pipes, based on drainage acreage and soil type retain between 3.32 and $18.86 \mathrm{~kg} /$ year of total P respectively.

4.2. Filtering $P$ on the edge: biogeochemical treatment of surface and subsurface runoff

Chemical treatment of drainage waters at the point of entry (i.e., end of tile) into the stream, edge-of-field, or within the stream (i.e., instream filtering) itself has gained much attention. In situ approaches being investigated and implemented to address P in the UMRB, GLW, and Chesapeake Bay include end-of-tile filtering (King et al., 2010), and in-stream treatments (Bryant et al., 2012; Penn et al., 2010). Alternative stream design may also offer some ability to address excess P (Roley et al., 2012). Removal of P by industrial byproducts such as fly ash, bone char, mine

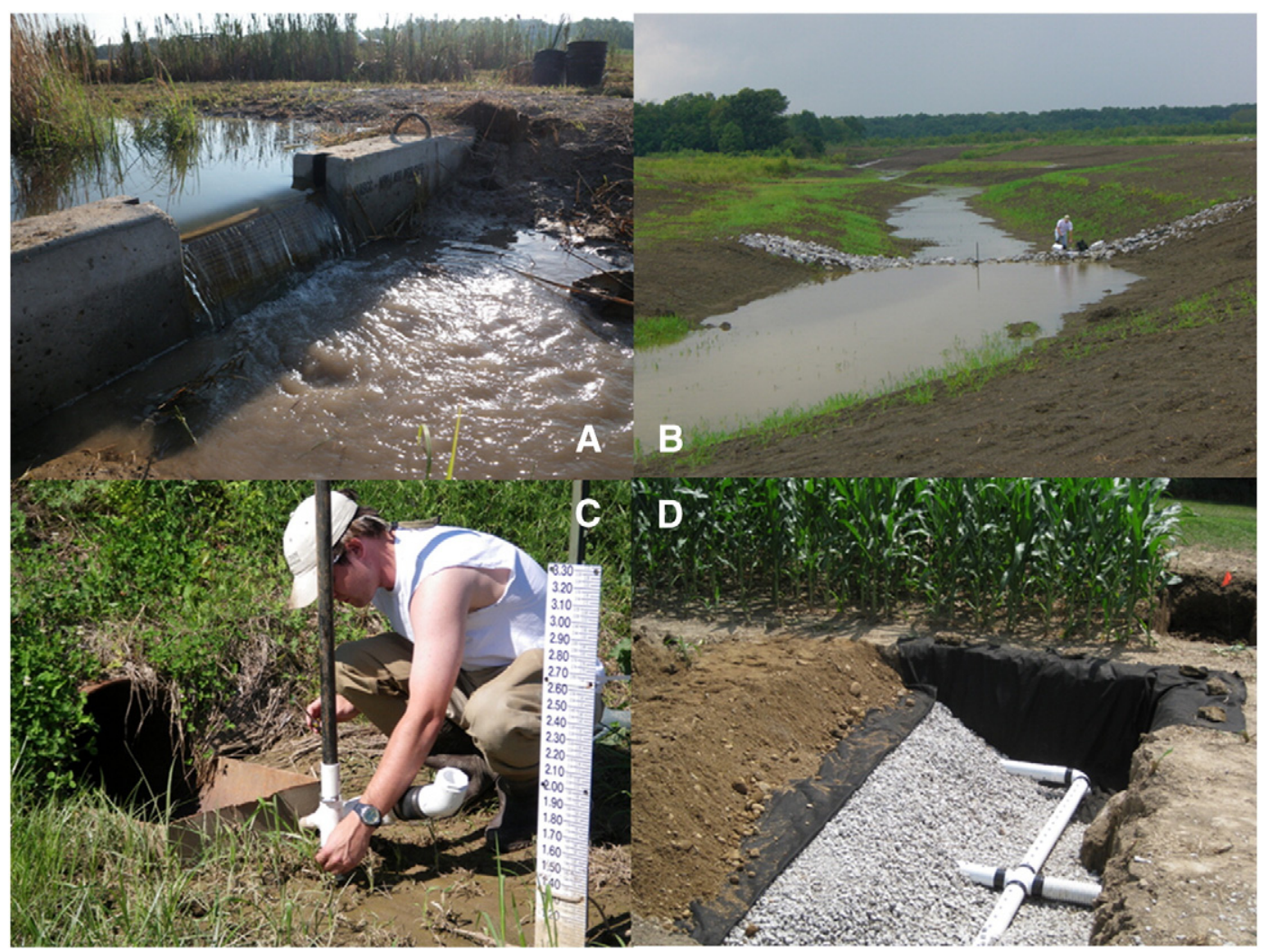

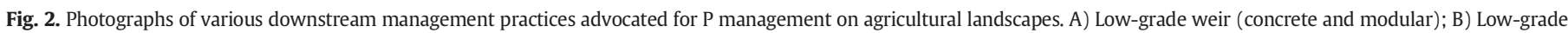
weir (rip-rap and earthen berm); C) Slotted pipe and pad (edge-of-field); and D) Blind inlet or French drain. 
tailings, and slags, all of which are rich in calcium, iron, aluminum, and/ or magnesium, has been investigated as potential filtering media (Agrawal et al., 2010; Agyei et al., 2002; Chazarenc et al., 2010; Drizo et al., 2006; Johansson and Gustafsson, 2000; King et al., 2010; McDowell et al., 2008; Namasivayam and Sangeetha, 2004). Steel slags in particular have proven to be very effective filters for removing $\mathrm{P}$ from municipal, domestic, and agricultural effluent (Baker et al., 1998; Bird and Drizo, 2010; Penn et al., 2010; Pratt et al., 2007; Weber et al., 2007). Greater than $70 \%$ of the dissolved $P$ in dairy unit wastes was removed using steel slag filters (Bird and Drizo, 2010). Many of the approaches rely on chemical reactions to bind or sorb $\mathrm{P}$ and require contact with the media being used to 'filter' P (King et al., 2010; Penn et al., 2010). To achieve this contact an increase in HRT is required. Increasing the HRT is usually accomplished by creating a more tortuous flow path by either packing the material more densely or lengthening the delivery system that houses the filter media. In both cases, the hydraulic conductivity is reduced, limiting this engineering approach to smaller flows.

Phosphorus delivery and management are also issues associated with animal operations and manure management. In recent decades, there has been a shift to confined animal feeding operations (CAFOs) in many areas across the US. Hauling manure long distances is expensive, so fields near CAFO's are commonly used for manure disposal (Moore et al., 1995; Sharpley et al., 1994; Shreve et al., 1995). Unfortunately, long-term manure application to the same fields in several eastern Coastal Plain states has resulted in soils containing excess $\mathrm{P}$ concentrations (Barker and Zublena, 1995; Cahoon and Ensign, 2004; Sallade and Sims, 1997; Sharpley and Halvorson, 1994). This is a serious soil P management issue because P movement via erosion, runoff, and deep P leaching in manure-treated fields (Mozaffari and Sims, 1994; Sharpley and Halvorson, 1994; Sims, 1993; Sims et al., 1998) causes eutrophication (Carpenter et al., 1998; Hansen et al., 2002; Sharpley et al., 1994). Some of the recent manure management practices for P mitigation involve treating manure with chemicals or applying by-products to soils (Novak and Watts, 2006; Smith et al., 2004a, 2004b). In one chemical method, alum is added directly to manure before application to soil (Warren et al., 2008). In this approach, the alum serves as an effective $\mathrm{P}$ binding agent that is capable of reducing soluble P levels, thereby, reducing off-site transport tendencies. Another approach of reducing $\mathrm{P}$ solubility is by adding $\mathrm{P}$ sequestering agents directly to soil (Leader et al., 2008; Makris et al., 2005). One material that has been recently evaluated is water treatment residuals (WTR), a by-product of the drinking water purification industry. The effectiveness of these by-products was recently reviewed by Ippolito et al. (2011) who reported that WTR is a cost effective material to sequester $\mathrm{P}$ in soils and that the sequestered $\mathrm{P}$ is almost irreversibly bound. Another approach to manage P in manures/ animal liters is through pyrolysis or gasification, whereby thermal energy is extracted from the material (Khan et al., 2009; Ro et al., 2010). The residual char or biochar from this process contains P (Gaskin et al., 2008; Novak et al., 2009). As an example, the P content in raw poultry litter was $<1 \%$, however, the $\mathrm{P}$ content in its biochar after pyrolysis increased to between 4 and 6\% by weight (Novak et al., 2009). This P recovery approach produces energy, while simultaneously producing a P-enriched by-product for possible transportation out of watersheds with high CAFO operations.

\subsection{Hydrology management - water table management at the end-of-tile}

Specifically in the GLW and UMRB water table management on tile drains is one such practice to address P management (Fausey, 2005; Strock et al., 2010). Water table management for most crop production is important during the growing season when the drainage system is managed so that the water table is effectively lowered to the depth of the drainage system outlet. The drainage water management technique known as controlled drainage was introduced in the early 1970s on agricultural lands in California to achieve agronomic and environmental goals (Willardson et al., 1972). Although this practice has been around for nearly four decades it is not widely adopted, and has been uncommon in the Midwest until recently. Controlled drainage is very effective in reducing the quantity of water and nitrate-N exported from subsurface drainage systems. In Minnesota, dissolved P losses were reduced by $63 \%$ while total P losses were reduced by $50 \%$ compared to conventional drainage practices (Feser et al., 2010).

For controlled drainage systems in the UMRB and GLW to be practical, certain conditions/criteria must be met: artificial drainage of the land is necessary, parallel or herringbone patterns are most suitable, in contrast to a random pattern drainage system; the land should be topographically flat with a slope of less than $0.5 \%$, although slopes up to $1 \%$ are feasible if the drainage system is installed along topographic contours; narrow drain spacing results in a flatter water table and reduces the risk of excess soil-water conditions during the growing season. The advent of new technology may allow the installation of these drainage systems where they are currently not appropriate. Where suitable conditions exist, controlled drainage offers a number of advantages over conventional drainage and can contribute to $\mathrm{P}$ concentration and load reductions.

\subsection{Hydrological manipulations and design of surface drainage to enhance particulate P retention}

The "delta" regions of the LMAV stretching from Cairo, IL to Baton Rouge, LA are synonymous with intense agricultural production. These regions contain soils that have an alluvial parent material containing clayey and silt-textured soils. These finely textured soils and low-lying landscape position lead to highly anaerobic saturated conditions, but subsurface drainage is uncommon because of poor soil porosity and slow soil hydraulic conductivity. Therefore, surface drainage is more commonly used rather than subsurface drainage. Significant surface drainage systems not only produce conditions conducive for row-crop agriculture, but also swiftly deliver nutrients and sediments to adjacent aquatic ecosystems. The proximity of agricultural headwater channels in the LMAV to the main-stem Mississippi River typically confers efficient delivery of P and sediments. Critical management problems of $\mathrm{P}$ in the LMAV include naturally high P content in soils (750-3500 $\mu \mathrm{g} / \mathrm{g}$ ), resulting in high surface delivery of particulate $\mathrm{P}(\mathrm{PP})$ when no anthropogenically derived fertilizers had been applied, as well as high (0.1-1 $\mathrm{mg} / \mathrm{L}$ ) dissolved $\mathrm{P}$ concentrations in the groundwater (Welch et al., 2009, 2010). Thus, two major sources of $\mathrm{P}$ in these landscapes include high PP loads due to sediment in surface runoff, and high concentrations of dissolved $\mathrm{P}$ in irrigation return flow.

Primary aquatic systems (i.e., first contact aquatic systems such as drainage ditches, tailwater recovery systems, restored river cutoffs) are ubiquitous features of the modern agricultural landscape. Thus, these systems are key locations to apply management tools that can reduce, primarily PP, delivery to downstream systems. With these practices, the nutrient spiral (or length of transport) of $\mathrm{P}$ is curtailed, and maintenance to remove trapped sediment $\mathrm{P}$ allows the replacement of accumulated $\mathrm{P}$ back onto the terrestrial agricultural landscape. Research shows that drainage ditches can retain $\mathrm{P}$ in the agricultural landscape (Kröger et al., 2008b, 2009; Moore et al., 2010). Kröger et al. (2008b) highlighted that vegetated drainage ditches varied in their retention of dissolved and particulate P based on season and water volume respectively. Annual retention of total inorganic P by the vegetated drainage ditch draining no-till cotton was $44 \pm 3 \%$. On average, ditches decreased dissolved P in the growing season by $61 \%$ while decreases were less during the non-growing season ( 45\%). Increased water volumes with storm events decreased the capacity of the ditch to trap particulate $\mathrm{P}$ (33\% $\mathrm{PO}_{4}-\mathrm{P}$ as compared to $52 \%$ particulate $\mathrm{P}$ retention). Moore et al. (2010) highlighted significant total inorganic P 
concentration and load decreases in vegetated and non-vegetated drainage ditches, highlighting and suggesting that settling capacity and sediment geochemical processes were primarily responsible for retaining total $\mathrm{P}$. Variations in ditch design are gaining much attention in the Midwest. One specific practice design, especially in Indiana, is two-stage ditches (Powell et al., 2007a, 2007b). Two-stage ditch design is based on an evaluation of channel forming discharges (Powell et al., 2006) and promotes interaction with the floodplain or bench of the associated ditch. Two-stage ditches facilitate denitrification in the benches (Roley et al., 2012) suggesting that they could also function as a P sink. Since the design promotes interaction with the floodplain through bench formation, any drainage waters flowing through or over the bench will slow; thereby providing suitable conditions for sedimentation. Any P associated with the sediments would be retained in the benches. Initial studies documenting the water quality benefits of two stage ditches have focused on sediment and $\mathrm{N}$ and not $\mathrm{P}$ (Roley et al., 2012). Phosphorus retention using the two-stage ditch design has not been studied. Similar to the two-stage approach is the over-wide or self-forming ditch design. This design is similar to the two-stage approach in that the formation of benches or floodplains within the ditch is created from deposited sediments. Any P associated with these sediments would not be transported further downstream.

Controlled surface drainage practices in drainage ditches are also being investigated in agricultural landscapes. These controlled surface drainage practices are installed in ditches as impedance barriers to flow, slowing runoff velocities, increasing sedimentation and increasing the hydraulic capacity and residence time of drainage ditches. Drainage ditches are typically ephemeral in the LMAV and thus, the increase in water volume and duration would enhance biological and geochemical conditions for $\mathrm{P}$ reduction. Innovative controlled surface drainage practices being advocated are called low-grade weirs (Kröger et al., 2008a) (Fig. 2). Low-grade weirs enhance hydraulic residence of the drainage ditch, decrease flow velocities, increase sediment settling and overall enhance P removal (Kröger et al., 2011). Low-grade weirs are innovative as they are stratified throughout the landscape based on the grade or slope of the drainage system. They are low in profile, are stair-stepped within the landscape, and provide multiple opportunities within a single drainage ditch for sedimentation, sediment sorption dynamics and biological immobilization (Fig. 3). Kröger et al. (2011) highlighted that controlled drainage structures of low-grade weirs and slotted risers, that increased hydraulic residence time of the drainage system above a conventional drainage system, had significant decreases in P concentrations and loads.

\subsection{Wetlands and treatment systems of landscape practices as tools for downstream P management}

Previous sections in this review have outlined some of the successes using management practices that create wetland-like conditions (hydrology and biogeochemistry) to retain $\mathrm{P}$ in the agricultural landscape. Wetlands themselves can be strategically located in agricultural landscapes, and downstream of $\mathrm{P}$ sources to retain P. Wetlands due to their landscape position store water, nutrients and particulates on both short- and long-term timescale (Bridgham et al., 1998; Kadlec and Wallace, 2008; Mitsch and Gosselink, 2007; Nichols, 1983; Reddy and DeLaune, 2008; Reddy et al., 1998). Moreover, wetlands both natural and constructed are often used to retain P in agricultural landscapes (Dunne et al., 2005; Kadlec et al., 2010; Koskiaho and Puustinen, 2005). Predominant biogeochemical processes governing P retention by wetlands include sorption and precipitation, sedimentation, and organic matter accretion, which is the single most important process for long-term P storage (Kadlec and Wallace, 2008; Reddy and DeLaune, 2008). A key component for using systems like wetlands or ditches to retain $\mathrm{P}$ downstream is to understand the dominant hydrological and biogeochemical processes governing retention and create favorable environmental conditions that favor retention processes rather than release processes. Examples of these include optimizing hydrology (hydraulic loading rate, HRT, water depths and hydroperiods) and biogeochemistry (sedimentation, sorption, and organic matter accretion). To do this, dynamic management of downstream wetland systems is required.

Natural floodplain wetlands are often hydrologically connected to rivers during high flow events and can trap large amounts of sediment and associated particulate P (Noe and Hupp, 2005). This retention can be a significant portion of annual river $\mathrm{P}$ loads (Noe and Hupp, 2009). The P trapping potential of natural floodplain wetlands suggests that the installation, creation, restoration and management of wetlands at floodplain scales can be effective practices for downstream retention and mitigation of $P$.

Placement of wetlands in strategic locations around the watershed to intercept $\mathrm{P}$ loads as well as maintaining their water and P storage capacity are important. Wetlands can be scaled in a hierarchical context to manage various $\mathrm{P}$ management problems i.e., $<100$ ac sub-watershed; $<2000$ ac basin scale; inline and offline riverine wetlands; and constructed wetlands to treat incoming waters. Hydrologic changes and agricultural development of downstream floodplain wetlands have occurred throughout the US and Lake Apopka's watershed in Florida is a good example of the relationship between historical increases in agricultural production, associated decrease in wetland acreage, $\mathrm{P}$ loading problems and eutrophication, and the more recent use of a constructed wetland to treat a nutrient impacted lake. The constructed wetland, which is called the "marsh flow-way" was put into operation by the St. Johns River Water Management District in November 2003. The flow-way is an emergent marsh system where water passes through a series of wetland cells, and treated water is pumped back into Lake Apopka. The system removes about $2.5 \mathrm{mT}\left(0.9 \mathrm{~g} \mathrm{~m}^{-2} \mathrm{yr}^{-1}\right)$ of total P per year, which equates to a removal efficiency of about $28 \%$.

Rather than a single large-scale constructed wetland to help reduce $P$ already in a lake, downstream approaches can include restoring the hydrology of historically isolated wetlands within agricultural landscapes to store increased amounts of water and subsequently retain P on the landscape, prior to waters reaching downstream receiving systems. Within the Lake Okeechobee Basin, (Florida) hydrologically isolated wetlands were evaluated to determine if hydrologic enhancement of historically isolated wetlands would contribute to increased amounts of water and nutrient retention (Dunne et al., 2007). They suggested that an increase in wetland area of between 5 and 20\% may increase wetland P storage up to $13 \mathrm{~kg} \mathrm{ha}^{-1}$. More recently, other initiatives within the Lake Okeechobee Basin include strategic approaches at the watershedscale to encourage property owners to store excess water on lands rather than draining it, in addition to potentially retaining regional water runoff. Through a combination of public and private projects about $132,000 \mathrm{ac}-\mathrm{ft}$ of water retention is available with about 100 participating landowners participating in the Dispersed Water Management Program. The ultimate goal is to provide 450,000 ac ft of retention/storage, which would also contribute to nutrient storage throughout the Northern Everglades (SFWMD, 2011).

Often the inability to sequester P within wetland systems is due to wetland perturbations from rainfall, insufficient wetland acreage for sufficient P-binding (Kellogg et al., 2000), and inappropriate environmental conditions that are conducive to long-term $P$ storage such as accrual and accretion of new soil. The ability of wetlands to retain P can be overwhelmed through hydrologic disturbances (i.e., rainfall, flooding, flow rates, turbulence, etc.) caused by storm and hurricane events (Bales, 2003; Borah et al., 2003; Burkholder et al., 2004). Novak et al. (2007) in a distinct example illustrated the impact of storm events had on an in-stream wetland's ability to retain dissolved $P$ by examining relationships between precipitation, outflow, dissolved P concentrations and loads. Seasonal and weather variability also can result in floodplain wetlands varying from sources to sinks of phosphate and particulate P (Noe and Hupp, 2007). These results imply that during 
A

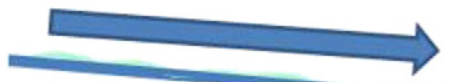

Little to no vegetation, little

biological activity

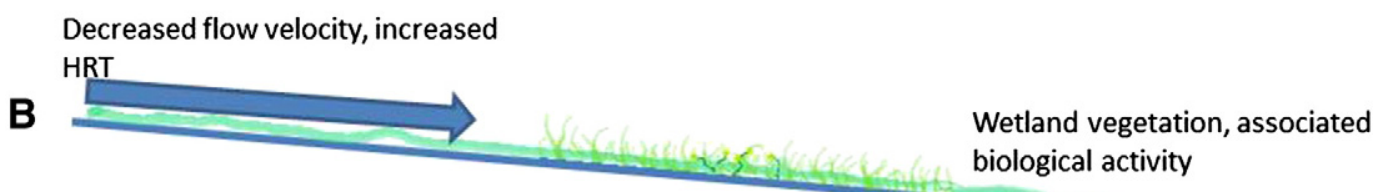

biological activity

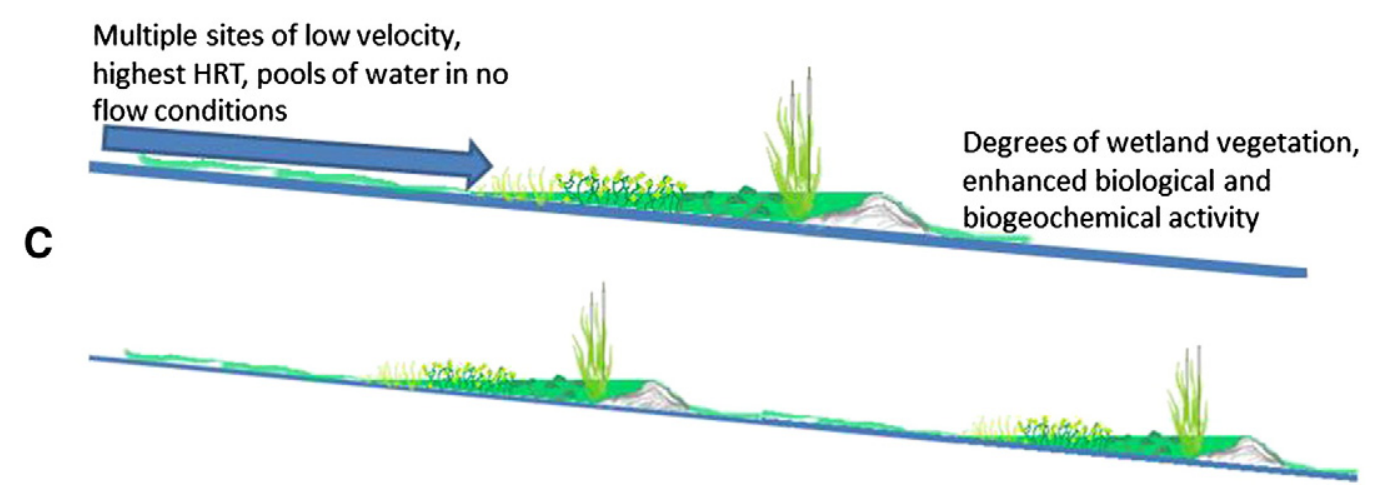

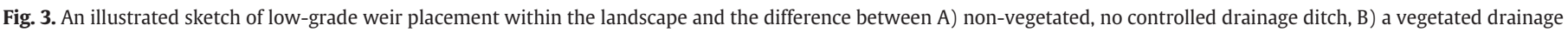
ditch, and C) a vegetated drainage ditch with low-grade weirs (with permission Kröger et al., 2012).

non-storm periods, an in-stream wetland can effectively store dissolved $\mathrm{P}$ through internal biotic and abiotic mechanisms, however, perturbations in hydrologic outflow patterns caused by extreme climatic events can erode and export sediment and cause short-term disturbance to vegetation and soils that results in P export greatly exceeding the ability of the wetland to store P.

King et al. (2010) and Penn et al. (2010) both note that when hydraulic conductivity is reduced, and HRT of systems is at capacity, nutrient assimilation, specifically $\mathrm{P}$, is significantly limited. Wetlands can lose significant HRT with sedimentation. To gauge the impact of an in-stream wetland on water quality, Novak et al. (2007) examined dissolved P export mass loads as a function of stream flow from a North Carolina sub-watershed with intensive livestock production. During low outflow conditions this in-stream wetland was capable of storing dissolved P in sediment pore water (Novak et al., 2004) and through chelation mechanisms with sediment organic matter (Novak and Watts, 2006). However, in high flow conditions, the system became a source of dissolved P to downstream systems.

Often the installation of wetland systems within the landscape is intimately tied to upstream management practices that reduce sediment loss. These management practices would include stream-bank stabilization and grade control structures to reduce bank sloughing. Management practices such as low-grade weirs, slotted pipes and slotted risers would all be management practices that would increase sedimentation upstream and reduce the sediment input load to the wetland system. Furthermore, if a treatment chain of wetlands were being constructed, managers could create a primary receiving wetland, or open water ponded area that would receive the majority of the sediment prior to effluent reaching lower chain wetlands. This wetland or open water system would optimize the environmental conditions conducive to sedimentation, and be accessible for management of the accumulated sediment, which may be of use in other landscape areas such as stabilizing stream banks or creating pads along open surface drainage ditches.

\section{Policy challenges of $\mathbf{P}$ management from the watershed scale}

The literature, and this review, are full of examples where landscape features such as drainage ditches (Kröger et al., 2008b; Sharpley et al., 2007), riparian zones (Novak et al., 2002), and wetlands (Kadlec et al., 2010; Moreno-Mateos et al. 2010; Novak et al., 2004; Reddy et al., 1999) can be used to improve water quality. Storing $\mathrm{P}$ in the landscape prior to $\mathrm{P}$ entering receiving aquatic systems can be effectively managed by increasing inundation, sediment retention, increasing sediment organic carbon contents, cation chelation, storage of $\mathrm{P}$ in sediment pore water, and in microbial biomass assimilation or incorporation (Novak et al., 2002, 2004; Reddy et al., 1999; Sharpley et al., 2007). All these mechanisms are interactive, downstream P management practices for effective P management in the landscape. Federal and State efforts to improve water quality by guiding conservation spending have paid little attention to the interactive role of downstream practices. The practice implemented, and the treatment chain of conservation practice interaction will be regional specific, as well as specific to the $\mathrm{P}$ type needing to be remediated. Once a chain of downstream practices is implemented with proper practice placement and design, an adaptive management strategy is needed to maintain practice effectiveness. As many management practices are affected by hydrology, biogeochemistry, and landscape position, an understanding of the dominant retention processes and what controls these processes are needed to effectively manage these systems to retain $\mathrm{P}$ in the agricultural landscape.

Our review above indicates that diverse downstream practices can trap and transform $P$ in ways that reduce export from agricultural watersheds. Much work remains to better understand how to site, 
design and manage these practices, singly and in combination, for greater environmental and socio-economic benefit. However, enough is known to suggest that these practices should be implemented more widely in regions such as the Great Lakes where $\mathrm{P}$ is a great concern. If practice implementation is coupled with site- and watershed-scale monitoring and modeling, we will be able to simultaneously advance water quality improvement and understand the effectiveness of the various practices. An adaptive management approach, in which improved scientific understanding resulting from a phased approach to BMP implementation would provide multiple environmental and socio-economic benefits.

Integrating downstream practices with one another and with source control practices will require an interdisciplinary, ecosystems based approach to water resource conservation planning at farm, watershed, and regional scales. New conservation planning tools must be developed to both determine the best placement of practices in the landscape and evaluate the water quality improvements of alternative conservation scenarios. Conservation spending must also adapt to this new approach, and mechanisms must be found to incentivize landowners to work collaboratively to develop and implement system- and watershed-scale solutions. For example, the Cooperative Conservation Partnerships Initiative in the 2008 Farm Bill could provide an opportunity to pilot such an approach.

Scientists, engineers and land managers have a good understanding of sediment transport processes at the watershed scale together with the complexity of soil $\mathrm{P}$ dynamics in wet systems. The major challenge though is implementing our scientific understanding into the ground practices, putting the right practice in the right place. A hydro-biogeochemically-based tool could provide a basis to compare practice effectiveness at a given landscape position. Furthermore land managers could use a tool to identify potential sediment deposition zones downstream of the most significant nutrient sources. Identifying hydrologic connections from field to stream is essential to optimizing practice placement. Yet most watershed models focus on landscape units too large (i.e., sub-basin elements) to make predictions about the efficiency of a given practice in a given place.

\section{Conclusion}

Agricultural landscapes across the US are intensively managed to successfully improve food, fiber and biofuel yields to meet the expected demand of an increasing world population. However, often these systems do not produce good water quality. By advocating right practice in the right place based on an understanding of hydrological and biogeochemical factors, improved downstream water quality effects could be added to sustainable intensification of agriculture. A tiered, multi-scale approach to $P$ management practices are required to mitigate downstream impacts of excess $P$ to aquatic systems. To be able to maximize the retention of dissolved and particulate $P$ requires optimizing different aspects of the hydro-biogeochemical cycle for any given landscape setting. Phosphorus characteristics, in addition to the physiographic setting of the issue, will determine the specific combination of practices that will yield the greatest effect on improving downstream water quality. Innovative practices, with improving technology for placement and implementation will increase the potential for P management. Collaborative frameworks of implementation, evaluation and planning at field, basin and watershed scales, as well as between coordinating agencies (i.e., research, extension and policy) will need to be established to ensure appropriate management plans are created, implemented and maintained. However, certain concepts associated with practices need to be integrated with management and maintenance for effective P management. These concepts include understanding short- and long-term $P$ retention mechanisms within a certain practice, the probability of implementation through incentivized mechanisms, and incorporating maintenance schedules if necessary to improve $P$ retention times and minimize exceeding retention capacity.

\section{Acknowledgments}

Environmental Defense Fund (EDF) organized a workshop in July 2011 on "Increasing the Assimilative Capacity of Agricultural Landscapes". The workshop brought together experts from multiple backgrounds studying the movement, transformation and storage of P. The authors would gratefully acknowledge funding from the Joyce Foundation for associated costs of the workshop. Robbie Kröger would like to acknowledge the Mississippi Agricultural Forestry Experiment Station and the Forest and Wildlife Research Center for support.

\section{References}

Agrawal SG, King KW, Moore JF, Levison P, McDonald J. Use of industrial byproducts to filter phosphorus and pesticides in golf green drainage water. J Environ Qual 2010;40:1272-80

Agyei NM, Strydom CA, Potgieter JH. The removal of phosphate ions from aqueous solution by fly ash, slag, ordinary Portland cement and related blends. Cem Concr Res 2002;32:1889-97.

Algoazany AS, Kalita PK, Czapar GF, Mitchell JK. Phosphorus transport through subsurface tile drainage and surface runoff form a flat watershed in east central Illinois, USA. J Environ Qual 2007;36:681-93.

Axt JR, Walbridge MR. Phosphate removal capacity of palustrine forested wetlands and adjacent uplands in Virginia. Soil Sci Soc Am J 1999;63:1019-31.

Baker MJ, Blowes DW, Ptacek CJ. Laboratory development of permeable reactive mixtures for the removal of phosphorus from onsite wastewater disposal systems. Environ Sci Technol 1998;32:2308-16.

Baldwin DS. Effects of exposure to air and subsequent drying on the phosphate sorption characteristics of sediments from a eutrophic reservoir. Limnol Oceanogr 1996;41:1725-32.

Bales JD. Effects of hurricane Floyd inland flooding: September-October 1999, on tributaries to Pamlico Sound, North Carolina. Estuaries 2003;26:1319-28.

Barker JC, Zublena JP. Livestock manure nutrient assessment in North Carolina. Proceedings of the seventh international symposium on agricultural and food processing wastes (ISAFPW95). St. Joseph, MI: Amer. Soc. Ag. Eng; 1995. p. 98-106.

Bird S, Drizo A. EAF steel slag filters for phosphorus removal from milk parlor effluent: the effects of solids loading, alternate feeding regimes and in-series design. Water 2010;2:484-99.

Bohlen PJ, Lynch S, Shabman L, Clark M, Shukla S, Swain H. Paying for environmental services from agricultural lands: an example from the northern Everglades. Front Ecol Environ 2009;7:46-55.

Boomer KM, Bedford BL. Groundwater-induced redox-gradients control soil properties and phosphorus availability across four headwater wetlands, New York, USA. Biogeochemistry 2008;90:259-74.

Borah DK, Bera M, Shaw S. Water, sediment, nutrient, and pesticide measurements in an agricultural watershed in Illinois during storm events. Trans ASAE 2003;46: 657-74.

Boyer TH, Persaud A, Banerjee P, Palomino P. Comparisons of low-cost and engineered materials for phosphorus removal from organic rich surface waters. Water Res 2011;45:4803-14.

Braskerud BC. Factors affecting phosphorus retention in small constructed wetlands treating agricultural non-point source pollution. Ecol Eng 2002;19:41-61.

Bridgham SD, Updegraff K, Pastor J. Carbon, nitrogen, and phosphorus mineralization in northern wetlands. Ecology 1998;79:1545-61.

Bryant RB, Buda AR, Kleinman PJA, Church CD, Saparito LS, Folmar GJ, et al. Using flue gas desulfurization gypsum to remove dissolved phosphorus from agricultural drainage waters. J Environ Qual 2012;41:664-71.

Burkart MR, James DE. Agricultural-nitrogen contributions to hypoxia in the Gulf of Mexico. J Environ Qual 1999;28(3):850-9.

Burkholder J, Eggleston D, Glasgow H, Brownie C, Reed R, Janowitz G, et al. Comparative impacts of two major hurricane seasons on the Neuse River and western Pamlico Sound ecosystem. Proc Natl Acad Sci 2004;101:9291-6.

Cahoon LB, Ensign SH. Spatial and temporal variability in excessive soil phosphorus levels in eastern North Carolina. Nutr Cycling Agroecosyst 2004;69:111-25.

Caraco NF, Cole JJ, Likens GE. Evidence for sulphate-controlled phosphorus release from sediments of aquatic systems. Nature 1989;341:316-8.

Carpenter S, Caraco NF, Correl DL, Howarth RW, Sharpley AN, Smith VH. Nonpoint pollution of surface waters with phosphorus and nitrogen. Issues Ecol 1998;3:1-12.

Chazarenc F, Filiatrault M, Brisson J, Comeau Y. Combination of slag, limestone and sedimentary apatite in columns for phosphorus removal from sludge fish farm effluents. Water 2010;40:500-9.

Dale VH, Kling CL, Meyer JL, Sanders J, Stallworth H, Armitage T, et al. Hypoxia in the northern Gulf of Mexico. Springer series on environmental management. New York: Springer Science; 2010.

Delgado JA, Groffman PM, Goddard T, Reicosky D, Lal R, Kitchen NR, et al. Conservation practices to mitigate and adapt climate change. J Soil Water Conserv 2011;66: 118A-29A.

Diaz RJ, Rosenberg R. Spreading dead zones and consequences for marine ecosystems. Science 2008;321:926-9.

Dodds WK, Bouska WW, Eitzmann JL, Pilger TJ, Pitts KL, Riley AJ, et al. Eutrophication of U.S. freshwaters: analysis of potential economic damages. Environ Sci Technol 2009;43:12-9. 
Drizo A, Forget C, Chapuis RP, Comeau Y. Phosphorus removal by electric arc furnace steel slag and serpentinite. Water Res 2006;40:1547-54.

Dunne EJ, Culleton N, O'Donovan G, Harrington R, Olsen AE. An integrated constructed wetland to treat contaminants and nutrients from dairy farmyard dirty water. Ecol Eng 2005;24:221-34

Dunne EJ, Smith J, Perkins DB, Clark MW, Jawitz JW, Reddy KR. Phosphorus storages in historically isolated wetland ecosystems and surrounding pasture uplands. Ecol Eng 2007;31:16-28.

Elser JJ, Bracken MES, Cleland EE, Gruner DS, Harpole WS, Hillebrand H, et al. Global analysis of nitrogen and phosphorus limitation of primary producers in freshwater marine and terrestrial ecosystems. Ecol Lett 2007;10:1135-42.

Enright P, Madramootoo CA. Phosphorus losses in surface runoff and subsurface drainage waters on two agricultural fields in Quebec. Proceedings, 8th international drainage symposium. St Joseph, MI: ASAE; 2004. p. 160-70.

Fausey NR. Drainage management for humid regions. AAAE 2005;14:209-14.

Feser SE, Strock JS, Sands GR, Birr AS. Controlled drainage to improve edge-of-field water quality in southwest Minnesota, USA. Drainage IX: proceedings of the ninth international drainage symposium, Quebec City, QC, June 13-16, 2010. St Joseph, MI: ASABE; 2010.

Gächter R, Müller B. Why the phosphorus retention of lakes does not necessarily depend on the oxygen supply to their sediment surfacfe. Limnol Oceanogr 2003;48: 929-33.

Gambrell RP, Patrick WHJ. The influence of redox potentials on the environmental chemistry of contaminants in soils and sediments. In: Hook DD, McKee WHJ Smith HK, Gregory J, Burrel JVG, DeVoe MR, et al, editors. The ecology and management of wetlands. Volume 1: ecology of wetlands. Portland, Oregon: Timber Press; 1988. p. 319-33.

Gaskin JW, Steiner C, Harris K, Das C, Bibens B. Effects of low-temperature pyrolysis conditions on biochar for agriculture use. Trans ASABE 2008;51:2061-9.

Gentry LE, David MB, Royer TV, Mitchell CA, Starks KM. Phosphorus transport pathways to streams in tile-drained agricultural watersheds. J Environ Qual 2007;36 408-15.

Hansen NC, Daniel TC, Sharpley AN, Lemunyon JL. The fate and transport of phosphorus in agricultural systems. J Soil Water Conserv 2002;57:408-17.

Heathwaite AL, Dils RM. Characterizing phosphorus loss in surface and subsurface hydrological pathways. Sci Total Environ 2000;251-252:523-38.

House WA. Geochemical cycling of phosphorus in rivers. Appl Geochem 2003;18: 739-48.

House WA, Denison FH. Exchange of inorganic phosphate between river waters and bed-sediments. Environ Sci Technol 2002;36:4295-301.

Ippolito JA, Barbarick KA, Elliot HA. Drinking water treatment residuals: a review of recent issues. J Environ Qual 2011;40:1-12.

Johansson L, Gustafsson JP. Phosphate removal from wastewaters using blast furnace slags and opoka - mechanisms. Water Res 2000;34:259-65.

Kadlec RH. Transport of phosphorus in wetlands. In: Reddy KR, O'Conner GA, Schelske CL, editors. Phosphorus biogeochemistry in subtropical ecosystems. Boca Raton FL.: Lewis Publishers; 1999. p. 355-75.

Kadlec RH, Wallace SD. Treatment wetlands. 2nd Edition. Boca Raton, FL: CRC Press 2008.

Kadlec RH, Roy SB, Munson RK, Charlton S, Brownlie W. Water quality performance of treatment wetlands in the Imperial Valley, California. Ecol Eng 2010;36:1064-9.

Kellogg RL, Lander CH, Moffit DC, Gollenham G. Manure nutrients relative to the capacity of cropland and pastureland to assimilate nutrients: spatial and temporal trends for the United States. Fort Worth, TX: USDA-NRCS, USDA-ERS, nps00-0579, GSA National Forms and Publication Center; 2000. [Available online at: http://www.nrcs.usda.gov/ technical/NRI/pubs/manntr.html].

Khan AA, deJong W, Jansens PJ, Spliethoff $\mathrm{H}$. Biomass combustion in fluidized bed boilers: potential problems and remedies. Fuel Process Technol 2009;90:21-50.

King KW, Smiley PCJ, Fausey NR. Hydrology of channelized and natural headwater streams. Hydrol Sci J 2009;54:929-48.

King KW, McDonald J, Moore JF, Agrawal SG, Fischer EN, Balogh JC. Nutrient and pesticide removal form laboratory-simulated tile drainage discharge. Trans ASABE 2010;53:769-77.

Kleinman PJA, Sullivan D, Wolf A, Brandt R, Dou Z, Kovar J, et al. Selection of water-extractable phosphorus test for manures and biosolids as an indicator of runoff loss potential. J Environ Qual 2007a;36:1357-67.

Kleinman PJA, Allen AL, Needelman BA, Sharpley AN, Vadas PA, Saparito LS, et al. Dynamics of phosphorus transfers from heavily manured coastal plain soils to drainage ditches. J Soil Water Conserv 2007b;62:225-35.

Kleinman PJA, Sharpley AN, McDowell RW, Flaten DN, Buda AR, Tao L, et al. Managing agricultural phosphorus for water quality protection: principles for progress. Plant Soil 2011;345. [Available online].

Klotz RL, Linn SA. Influence of factors associated with water level drawdown on phosphorus release from sediments. J Lake Reservoir Manage 2001;17:48-54.

Koskiaho J, Puustinen M. Function and potential of constructed wetlands for the control of $\mathrm{N}$ and $\mathrm{P}$ transport from agriculture and peat production in boreal climate. J Environ Sci Health Part A Toxic/Hazard Subst Environ Eng 2005;40:1265-79.

Kröger R, Holland MM, Moore MT, Cooper CM. Agricultural drainage ditches mitigate phosphorus loads as a function of hydrological variability. J Environ Qual 2008a;37:107-13.

Kröger R, Cooper CM, Moore MT. A preliminary study of an alternative controlled drainage strategy in surface drainage ditches: low-grade weirs. Agric Water Manage 2008b;95:678-84

Kröger R, Moore MT, Locke MA, Cullum RF, Steinriede RW, Testa S, et al. Evaluating the influence of wetland vegetation on chemical residence time in Mississippi Delta drainage ditches. Agric Water Manage 2009;96:1175-9.
Kröger R, Moore MT, Farris JL, Gopalan M. Evidence for the use of low-grade weirs in drainage ditches to improve nutrient reductions from agriculture. Water Air Soil Pollut 2011;221:223-34.

Kröger R, Moore MT, Thornton KW, Farris JL, Prevost JD, Pierce SC. Tiered on-the-ground implementation projects for Gulf of Mexico water quality improvements. Journal of Soil and Water Conservation 2012;67(4):94A-9A.

Kronvang B, Bechmann M, Pedersen ML, Flynn N. Phosphorus dynamics and export in streams draining micro-catchments: development of empirical models. J Plant Nutr Soils Sci 2003;166:469-74.

Leader JW, Dunne EJ, Reddy KR. Phosphorus sorbing materials: sorption dynamics and physicochemical characteristics. J Environ Qual 2008;37:174-81.

Lijklema L. Interaction of orthophosphate with iron (III) and aluminum hydroxides. Environ Sci Technol 1980;14:537-41.

Lucassen ECHET, Smolders AJP, Lamers LPM, Roelofs JGM. Water table fluctuations and groundwater supply are important in preventing phosphate-eutrophication in sulphate-rich fens: consequences for wetland restoration. Plant Soil 2005;269: 109-15.

Macrae ML, English MC, Schiff SL, Stone M. Intra-annual variability in the contribution of tile drains to basin discharge and phosphorus export in a first order agricultural catchment. Agric Water Manage 2007;92:171-82.

Maguire RO, Rubæk GH, Haggard BE, Foy BH. Critical evaluation of the implementation of mitigation options for phosphorus from field to catchment scales. J Environ Qual 2009;38:1989-97.

Makris KC, Harris WG, O'Connor GA, Obreza TA, Elliot HA. Physicochemical properties related to long-term phosphorus retention by drinking water. Environ Sci Technol 2005;39:4280-9.

Martin HW, Ivanoff DB, Graetz DA, Reddy KR. Water table effects on histosol drainage water carbon, nitrogen and phosphorus. J Environ Qual 1997;26:1062-71.

Maynard JJ, O'Green AT, Dahlgren RA. Bioavailability and fate of phosphorus in constructed wetlands receiving agricultural runoff in the San Joaquin Valley, California. J Environ Qual 2009;38:360-72.

McDowell RW, Sharpley AN, Bourke W. Treatment of drainage water with industrial by-products to prevent phosphorus loss from tile-drained land. J Environ Qual 2008;37:1575-82.

Mitsch WJ, Gosselink JG. Wetlands. Hoboken, New Jersey: John Wiley \& Sons, Inc. 2007.

Mitsch WJ, Jørgensen SE. Ecological engineering and ecosystem restoration. Hoboken, New Jersey: John Wiley \& Sons, Inc.; 2004.

Moore PAJ, Daniel TC, Sharpley AN, Woods DC. Poultry manure management: environmentally sound options. J Soil Water Conserv 1995;50:321-7.

Moore MT, Kröger R, Locke MA, Cullum RF, Steinriede RW, Testa S, et al. Nutrient mitigation capacity in Mississippi Delta, USA drainage ditches. Environ Pollut 2010;158: 175-84.

Moreno-Mateos D, Pedrocchi C, Comin FA. Effects of wetland construction on water quality in a semi-arid catchment degraded by intensive agricultural use. Ecol. Eng. 2010;36:631-9.

Mozaffari M, Sims JT. Phosphorus availability and sorption in an Atlantic coastal plain watershed dominated by animal-based agriculture. Soil Sci 1994:157:97-107.

Namasivayam C, Sangeetha D. Equilibrium and kinetic studies of adsorption of phosphate onto $\mathrm{ZnCl}_{2}$ activated coir pith. J Colloid Interface Sci 2004;280:359-65.

Newman S, Pietro K. Phosphorus storage and release in response to flooding: implications for Everglades stormwater treatment areas. Ecol Eng 2001;18:23-38.

Nichols DS. Capacity of natural wetlands to remove nutrients from wastewater. J Water Pollut Control Fed 1983;55:495-505.

Noe GB, Hupp CR. Carbon, nitrogen and phosphorus accumulation in floodplains of the Atlantic coastal plain rivers, USA. Ecol Appl 2005;5:1178-90.

Noe GB, Hupp CR. Seasonal variation in nutrient retention during inundation of a short-hydroperiod floodplain. River Res Appl 2007;23:1088-101.

Noe GB, Hupp CR. Retention of riverine sediment and nutrient loads by coastal plain floodplains. Ecosystems 2009;12:728-46.

Novak JM, Watts DW. Phosphorus sorption by sediments in a southeastern coastal plain in-stream wetland. J Environ Qual 2006;35:1975-82.

Novak JM, Hunt PG, Stone KC, Watts DW, Johnson MH. Riparian zone impact on the phosphorus movement to a coastal plain black water stream. J Soil Water Conserv 2002;57:127-33.

Novak JM, Stone KC, Szogi AA, Watts DW, Johnson MH. Dissolved phosphorus retention and release from a coastal plain in-stream wetland. J Environ Qual 2004;33: 394-401.

Novak JM, Szogi AA, Stone KC, Watts DW, Johnson MH. Dissolved phosphorus export from an animal waste impacted in-stream wetland: Responses to tropical storm and hurricane disturbances. J Environ Qual 2007;36:790-800.

Novak JM, Lima I, Xing B, Gaskin JW, Steiner C, Das KC, et al. Characterization of designer biochar produced at different temperatures and their effects on a loamy sand. Ann Environ Sci 2009;3:195-206

Olde Venterink H, Belgers JDM, Verhoeven JTA. Control of environmental variables on species density in fens and meadows: importance of direct effects and effects through community biomass. J Ecol 2001;89:1033-40.

Olson TC. Restoring the productivity of a glacial till soil after topsoil removal. J. Soil and Water Conserv. 1977;32:130-2.

Patrick WHJ, Khalid RA. Phosphate release and sorption by soils and sediments: effect of aerobic and anaerobic conditions. Science 1974;186:53-5.

Penn CJ, McGrath JM, Bryant RB. Ditch drainage management for water quality improvement In: Moore MT, Kröger R, editors. Agricultural drainage ditches: mitigation wetlands for the 21st century. Trivandrum, India: Research Signpost Publishing; 2010.

Petrolia DR, Gowda RH. Missing the boat: Midwest farm drainage and Gulf of Mexico hypoxia. Rev Agric Econ 2010;28:240-53. 
Pionke HB, Gburek WJ, Sharpley AN, Schnabel RR. Flow and nutrient export patterns for an agricultural hill-land watershed. Water Resour Res 1996;32:1795-804.

Powell GE, Mecklenburg DE, Ward AD. Evaluating channel-forming discharges: a study of large rivers in Ohio. Trans ASABE 2006;49:35-46.

Powell GE, Ward AD, Mecklenburg DE, Draper J, Word W. Two-stage channel systems: part 2, case studies. J Soil Water Conserv 2007a;62:286-96.

Powell GE, Ward AD, Mecklenburg DE, Jayakaran AD. Two-stage channel systems: part 1, a practical approach for sizing agricultural ditches. J Soil Water Conserv 2007b;62: 277-86.

Pratt C, Shilton AN, Pratt S, Haverkamp RG, Bolan NS. Phosphorus removal mechanisms in active slag filters treating waste stabilisation pond effluent. Environ Sci Technol 2007:41:3296-301.

Preston SD, Alexander RB, Schwarz GE, Crawford CG. Factors affecting stream nutrient loads: a synthesis of regional SPARROW model results for the continental United States. J Am Water Resour Assoc 2011;47:891-915.

Rabalais NN. Nitrogen in aquatic ecosystems. Ambio 2002;31:102-12.

Rabalais NN, Wiseman WJ, Turner RE, SenGupta BK, Dortch Q. Nutrient changes in the Mississippi River and responses on the adjacent continental shelf. Estuaries 1996;19:386-407.

Rabalais NN, Turner RE, Wiseman WJ. Gulf of Mexico, a.k.a. "the dead zone". Annu Rev Ecol Syst 2002;33:235-63.

Rebich RA, Houston NA, Mize SV, Pearson DK, Ging PB, Hornig CE. Sources and delivery of nutrients to the north-western Gulf of Mexico from streams in the south-central United States. J Am Water Resour Assoc 2011;47:1-26.

Reddy KR, Delaune RD. Biogeochemistry of wetlands. Boca Raton, FL: CRC Press; 2008. p. 325-403.

Reddy KR, Conner GAO, Gale PM. Phosphorus sorption capacities of wetland soils and stream sediments impacted by dairy effluent. J Environ Qual 1998;27:438-47.

Reddy KR, Kadlec RH, Flaig E, Gale PM. Phosphorus retention in streams and wetlands: a review. Crit Rev Environ Sci Technol 1999;29:83-146.

Richardson CJ. Mechanisms controlling phosphorus retention capacity in freshwater wetlands. Science 1995;228:1424-7.

Ritzema HP, Nijland HJ, Croon FW. Subsurface drainage practices: from manual installation to large scale implementation. Agric Water Manage 2006;86:60-71.

Ro KS, Cantrell KB, Hunt PG. High-temperature pyrolysis of blended animal manure for producing renewable energy and value added biochar. Ind Eng Chem Res 2010;49: 10125-31.

Robertson DM, Schwarz GE, Saad DA, Alexander RB. Incorporating uncertainty into the ranking of SPARROW model nutrient yields from the Mississippi/Atchafalaya River basin watersheds. J Am Water Resour Assoc 2009;45:534-49.

Roden EE, Edmonds JW. Phosphate mobilization in iron-rich anaerobic sediments: microbial Fe (III)-oxide reduction versus iron-sulfide formation. Archiv Hydrobiol 1997;139:347-78.

Roelofs JGM. Inlet of alkaline river water into peaty lowlands: effects on water quality and Stratiotes aloides L. stands. Aquat Bot 1991;39:267-93.

Roley S, Tank J, Stephen M, Johnson L, Beaulieu J, Witter J. Floodplain restoration enhances denitrification and reach-scale nitrogen removal in an agricultural stream. Ecol Appl 2012;22(1):281-97.

Sallade YE, Sims JT. Phosphorus transformations in the sediments of Delaware's agricultural drainageways: 1. Phosphorus forms and sorption. J Environ Qual 1997;26: 1571-9.

SFWMD. Dispersed water management program: shallow water retention benefits water resources and the environment. South Florida Water Management District; 2011 [Available online: www.sfwmd.gov].

Sharpley AN. Soil phosphorus dynamics: agronomic and environmental impacts. Ecol Eng 1995;5:261-79.

Sharpley AN, Halvorson AD. The management of soil phosphorus availability and its impact on surface water quality. In: Lal R, Stewart BA, editors. Soil processes and water quality. Boca Raton, FL: Lewis, Publishers; 1994. p. 7-90.

Sharpley AN, Chapra SC, Wedepohl R, Sims JT, Daniel TC, Reddy KR. Managing agricultural phosphorus for protection of surface waters: issues and options. J Environ Qual 1994;23:437-51.

Sharpley AN, Weld JL, Beegle PJA, Gburek WJ, Moore PA, Mullins G. Development of phosphorus indices for nutrient management planning strategies in the United States. J Soil Water Conserv 2003;58:137-52.
Sharpley AN, Krogstad T, Kleinman PJA, Haggard BE, Shigaki F, Saparito LS. Managing natural processes in drainage ditches for nonpoint source phosphorus control. J Soil Water Conserv 2007;62:197-206.

Sharpley AN, Kleinman PJA, Heathwaite AL, Gburek WJ, Folmar GJ, Schmidt JP. Phosphorus loss from an agricultural watershed as a function of storm size. J Environ Qual 2008;37:362-8.

Sharpley AN, Kleinman PJA, Jordan P, Bergström L, Allen AL. Evaluating the success of phosphorus management from field to watershed. J Environ Qual 2009:38:1981-8.

Shreve BR, Moore PAJ, Daniel TC, Edwards DR, Miller DM. Reduction of phosphorus in runoff from field-applied poultry litter using chemical amendments. J Environ Qual 1995;24:106-11.

Sims JT. Environmental soil testing for phosphorus. J Prod Agric 1993;6:591-607.

Sims JT, Simard RR, Joern BC. Phosphorus losses in agricultural drainage: historical perspective and current research. J Environ Qual 1998;27:277-93.

Smith DR, Livingston SJ, submitted for publication. Managing farmed prairie potholes using blind inlets to improve water quality. Soil Use and Management.

Smith DR, Moore PAJ, Miles DM, Haggard BE, Daniel TC. Decreasing phosphorus runoff losses from land-applied poultry litter with dietary modifications and alum addition. J Environ Qual 2004a;33:2210-6.

Smith DR, Moore PAJ, Maxwell CV, Haggard BE, Daniel TC. Reducing phosphorus runoff from swine manure with dietary phytase and aluminum chloride. J Environ Qual 2004b;33:1048-54.

Smith DR, Livingston SJ, Zuercher BW, Larose M, Heathman GC, Huang C. Nutrient losses from row-crop agriculture in Indiana. J Soil Water Conserv 2008;63:396-409.

Strock JS, Kleinman PJA, King KW, Delgado JA. Drainage water management for water quality protection. J Soil Water Conserv 2010;65:131A-6A.

Sylvan JB, Dortch Q, Nelson DM, Maier Brown AF, Morrison W, Ammerman JW. Phosphorus limits phytoplankton grown on the LA shelf during the period of hypoxia formation. Environ Sci Technol 2006;40:7548-53.

Thomas DL, Shirmohammadi A, Lowrance RR, Smith MC. Drainage-subirrigation effect on water quality in Georgia flatwoods. J Irrig Drain Eng 1991;117:123-37.

Tomer MD, Moorman TB, Rossi CG. Assessment of the Iowa River's South Fork watershed: part 1. Water quality. J Soil Water Conserv 2008:63:360-70.

USEPA. Hypoxia advisory panel report and comments. Available at: http://www.epa gov/sab/panels/hypoxia_adv_panel.htm. [Last Accessed 6/29/2011].

Walbridge MR, Struthers JP. Phosphorus retention in non-tidal palustrine forested wetlands in the mid-Atlantic region. Wetlands 1993;13:84-94.

Warren JG, Penn CJ, McGrath JM, Sistani KR. The impact of alum additions on organic $\mathrm{P}$ transformations in poultry litter and soils receiving alum-treated poultry litter. J Environ Qual 2008;37:469-76.

Weber D, Drizo A, Twohig E, Bird S, Ross D. Upgrading constructed wetlands: phosphorus reduction from a dairy effluent using EAF steel slag filters. Water Sci Technol 2007;56:135-214.

Welch HL, Kingsbury JA, Tollett RW, Seanor RC. Quality of shallow groundwater and drinking water in the Mississippi Embayment-Texas coastal uplands aquifer system and the Mississippi River Valley alluvial aquifer, South-Central United States, 1994-2004. Reston, VA: U.S. Geological Survey Scientific Investigations; 2009

Welch HL, Rose CE, Kingsbury JA. Occurrence of phosphorus in groundwater and surface water of northwestern Mississippi. Proceedings of the Mississippi water resources conference, 2011; 2010. [November 3-5].

Wetzel RG. Limnology: lake and river ecosystems. 3rd Edition. New York, NY: Academic Press; 2001.

Wilhelm WW, Hess JR, Karlen DL, Johnson JMF, Muth DJ, Baker JM, et al. Balancing limiting factors and economic drivers for sustainable Midwest US agricultural residue feedstock supplies. Ind Biotechnol 2010;6:271-87.

Willardson LS, Meek BD, Grass LB, Dickey GL, Bailey JW. Nitrate reduction with submerged drains. Trans ASAE 1972;35:84-90.

Zucker LA, Brown LC. Agricultural drainage: water quality impacts and subsurface drainage studies in the Midwest. Ohio State University extension bulletin, 871 $\mathrm{OH}$ : The Ohio State University; 1998. 